\title{
PENGGUNAAN AGUNAN PADA AKAD MUSYARAKAH BANK SYARIAH MENURUT UNDANG-UNDANG NOMOR 21 TAHUN 2008 TENTANG PERBANKAN SYARIAH
}

\author{
oleh \\ Deny Wahyudi Oktora \\ Dewi Rohayati,
}

\begin{abstract}
ABSTRAK
Karakteristik Musyarakah yang dapat digolongkan sebagai salah satu kontrak investasi apabila laba bisnisnya besar, maka kedua belah pihak akan mendapat bagian yang besar pula jika keuntungan dari bisnisnya kecil maka kedua belah pihak yang melakukan kontrak akan mendapatkan keugian yang kecil dan apabila mengalami kerugian atau collapse, maka pihak pengelola dan pihak pemodal akan bersama-sama menanggung segala kerugian yang di derita, sesuai dengan porsi modal yang disepakati. Berdasarkan prakteknya hal demikian sulit diterapkan karena pihak bank tidak ingin tau segala macam kerugian yang di derita oleh nasabah pengelola dan baik itu dari faktor kesengajaan atau karena faktor kelalaian sehingga tetap saja agunan yang dimintakan untuk dijadikan salah satu syarat oleh pihak Bank Syariah kepada nasabah/pengelola dana pada akhirnya harus tetap di eksekusi dan hal itu dilakukan guna mengembalikan sejumlah dana/modal yang telah diberikan oleh pihak Bank Syariah yang telah ditentukan sebelumnya. Hasil penelitian ini menyimpulkan bahwa penggunaan agunan pada bank syariah menurut ketentuan hukum positif adalah untuk melindungi kepentingan bank sedangkan menurut ketentuan syariat islam tidak ada jaminan namun untuk menghindari penyimpangan maka agunan boleh dimintakan. Dan penyelesaian kredit macet terkait agunan dalam bank syariah ini yaitu dengan restrukturisasi dengan cara penjadwalan ulang (Rescheduling), persyaratan kembali (Reconditioning), Penataan Kembali (Restructuring). Apabila sudah ada jadwal yang diberikan kepada nasabah tetapi nasabah tidak dapat memenuhi kewajibannya dan tidak cepat melapor kepada pihak bank, maka pihak bank akan menunggu selama periode tertentu dan nasabah akan diberikan SPKT (surat pemberitahuan keterangan terlambat). Jika dalam waktu 3 bulan nasabah belum melakukan kewajibannya maka pihak Bank akan memberikan SP 1 (surat peringatan 1) sampai dengan SP 3. Jika tidak ada respon dari pihak nasabah setelah diberikan SP 3 maka agunan harus di eksekusi.
\end{abstract}

Kata Kunci : Penggunaan Agunan, Akad Musyarakah, Bank Syariah,

\section{PENDAHULUAN}

\section{Latar Belakang}

Bangsa Indonesia adalah suatu bangsa yang berdaulat, bangsa Indonesia mempunyai dasar Negara dan Undang-Undang Dasar Negara Republik Indonesia sendiri. Negara kesatuan Republik Indonesia mempunyai Dasar Negara yakni Pancasila. Undang-Undang Dasar yang ada di Negara Kesatuan Republik Indonesia adalah Undang-Undang Dasar 1945, (yang selanjutnya disingkat UUD 1945). UUD 1945 memberi penegasan bahwa Negara Kesatuan Republik Indonesia merupakan Negara hukum.

Bangsa Indonesia mayoritas penduduknya adalah muslim, maka hadirnya Bank Syariah merupakan pilihan yang tepat bagi masyarakat muslim di Indonesia, karena ketentuan yang digunakan oleh Bank Syariah yaitu ketentuan bagi hasil yang mengenyampingkan urusan riba dan sesuai dengan ajaran Islam. Selain itu Bank Syariah lebih tinggi kualitas moralnya, etika dan bisnisnya dibandingkan dengan bank konvensional. 
Ketentuan Undang-Undang Nomor 10 Tahun 1998 Tentang Perbankan yaitu menyangkut bank konvensional menjadi Bank Syariah serta ketentuan diperbolehkannya Bank Konvensional mempunyai cabang sebagai Bank Syariah. Dua ketentuan di atas sangat menarik jika dikaitkan dengan ketentuan modal disetor untuk Bank Syariah, yaitu bahwa untuk Bank Syariah modalnya tidak boleh bersumber dari dana yang diharamkan menurut ajaran Islam.

Lembaga keuangan Syariah merupakan lembaga keuangan yang tidak hanya mengedepankan profit oriented saja, melainkan suatu lembaga keuangan yang juga mengedepankan kemaslahatan masyarakat sesuai dengan tuntutan Syariah yang menjadi landasan dari semua lembaga keuangan Syariah.

Undang-Undang Nomor 21 Tahun 2008 Tentang Perbankan Syariah terbentuk sebagai jawaban atas meningkatnya kebutuhan masyarakat Indonesia akan jasa-jasa Perbankan Syariah. Produk-produk yang ada di Bank Syariah diklarifikasi berdasarkan empat macam kategori perjanjian yang dikenal dalam islam. Dalam Perbankan Syariah, setiap produk yang dikeluarkan didasarkan pada prinsip titipan, jual beli, sewa menyewa, bagi hasil, dan akad yang sifatnya sosial (tabarru).

Landasan hukum tentang Perbankan Syariah di atur dalam Undang-Undang Nomor 21 tahun 2008 Tentang Perbankan Syariah, dalam Undang-undang tersebut Pasal 1 angka 12 menyatakan prinsip Syariah adalah prinsip hukum islam dalam kegiatan Perbankan berdasarkan Fatwa yang dikeluarkan oleh lembaga yang memiliki kewenangan dalam penetapan Fatwa di bidang Syariah. Pasal tersebut menegaskan bahwa Fatwa berlaku juga sebagai dasar Hukum Perbankan Syariah.

Landasan hukum tentang Musyarakah diatur dalam Undang-Undang Nomor 21 Tahun 2008 Tentang Perbankan Syariah, terdapat dalam Pasal 19 huruf c yang menentukan bahwa kegiatan usaha bank umum Syariah meliputi menyalurkan pembiayaan bagi hasil berdasarkan akad Mudharabah, akad Musyarakah atau akad lain yang tidak bertentangan dengan prinsip Syariah.

Litelatur fiqih menyatakan bahwa Musyarakah adalah akad kerjasama antara dua pihak atau lebih untuk kegiatan usaha tertentu. Masing-masing memberikan kontribusi dana atau pekerjaan sekaligus dengan kesepakatan bahwa keuntungan dan kerugian akan ditanggung bersama sesuai dengan kesepakatan. Jadi, Musyarakah adalah perjanjian kesepakatan bersama antara beberapa pemilik modal untuk menyertakan modal sahamnya pada suatu proyek yang biasanya berjangka waktu panjang ${ }^{1)}$.

Selain landasan hukum di atas, dalam Al-Qur'an maupun hadist secara tersurat dijelaskan terkait Musyarakah itu sendiri diantaranya dalam Qur'an Surat Shad ayat 24 yang artinya "dan sesungguhnya kebanyakan dari orang-orang bersyarikat itu sebagian dari mereka berbuat zalim kepada sebagian lain, kecuali orang yang beriman dan mengerjakan amal shaleh; dan amat sedikitlah mereka ini".

Hadist yang diriwayatkan oleh Abu Daud dari Abu Hurairah, rasulullah SAW bersabda : "Allah SWT. Berfirman "aku adalah pihak ketiga dari dua orang yang bersyarikat selama satu pihak tidak menghianat pihak yang lain. Jika salah satu pihak telah berkhianat, aku keluar dari mereka." (HR.Abu Daud, yang di sahkan oleh al-hakim, dari Abu Hurairah)

Pembuatan kontrak/akad tentunya akan dimulai dengan hal-hal yang bersifat umum, para pihak biasanya akan melakukan pembicaraan satu sama lain. Sebab, jika suatu kontrak tidak di definisikan secara jelas mengenai sesuatu yang dimaksud bisa menimbulkan persoalan-persoalan yang baru ${ }^{2)}$. Menurut hukum Perjanjian Islam kebebasan berkontrak dimaksudkan kebebasan seseorang untuk membuat perjanjian apapun dan berisi apa saja

1) Asmuni Mth., Aplikasi Musyarakah dalam Perbankan Islam., Jurnal Al-mawari edisi XII, Yogyakarta,

2) Richard Burton Simatupang, Atas Hukum dalam Bisnis, PT Rineka Cipta, Jakarta, 2003. hlm.33 
sesuai dengan kepentingannya dalam batas-batas kesusilaan dan ketertiban umum, sekalipun perjanjian itu bertentangan dengan Pasal-pasal hukum perjanjian.

Musyarakah telah diatur dalam ketentuan Fatwa Dewan Syariah Nasional Majelis Ulama Indonesia Nomor 08/DSN-MUI/IV/2000 Tentang Pembiayaan Musyarakah, yang menyebutkan bahwa kebutuhan masyarakat untuk meningkatkan kesejahteraan dan usaha terkadang memerlukan dana dari pihak lain, antara lain melalui pembiayaan Musyarakah yaitu pembiayan berdasarkan akad kerjasama antara dua pihak atau lebih untuk suatu usaha tertentu dimana masing-masing pihak memberikan konstribusi dana dengan ketentuan bahwa keuntungan dan resiko akan ditanggung bersama sesuai kesepakatan. Pembiayaan Musyarakah apabila termasuk dalam kerjasama bukan termasuk utang-piutang seharusnya tidak disyaratkan dalam perjanjian untuk meminta agunan.

Fungsi agunan yang ada, dihubungkan dengan faktor-faktor yang mempengaruhi akad Musyarakah menjadi kendala, apakah benar Bank Syariah menerapkan konsep Musyarakah sesuai konsep dasar Musyarakah. Sejak di sahkannya Undang-undang No 21 Tahun 2008 Tentang Perbankan Syariah maka banyak perbedaan pendapat mengenai Musyarakah, di dalam Undang-Undang Nomor 21 Tahun 2008 Tentang Perbankan Syariah mewajibkan penggunaan agunan sebagai salah satu syarat sesuai yang tertera dalam Pasal 23 yang menyebutkan bahwa:

(1)Bank Syariah dan/atau Unit Usaha Syariah bahwa mempunyai keyakinan atas kemauan dan kemampuan calon Nasabah penerima Fasilitas untuk melunasi seluruh kewajiban pada waktunya, sebelum Bank Syariah dan/atau Unit Usaha Syariah menyalurkan dana kepada nasabah penerima fasilitas

(2) untuk memperoleh keyakinan sebagaimana dimaksud pada ayat (1), Bank Syariah dan/atau Unit Usaha Syariah wajib melakukan penilaian yang saksama terhadap watak, kemampuan, modal, agunan, dan prospek usaha dari calon nasabah penerima fasilitas.

Sedangkan dalam Fatwa Dewan Syariah Nasional Majelis Ulama Indonesia dalam point ke 3 menyebutkan bahwa ; "pada prinsipnya, dalam pembiayaan Musyarakah tidak ada jaminan, namun untuk menghindari penyimpangan, Lembaga Keuangan Syariah dapat meminta jaminan".

Karakteristik Musyarakah yang dapat digolongkan sebagai salah satu kontrak investasi apabila laba bisnisnya besar, maka kedua belah pihak akan mendapat bagian yang besar pula jika keuntungan dari bisnisnya kecil maka kedua belah pihak yang melakukan kontrak akan mendapatkan keugian yang kecil dan apabila mengalami kerugian atau collapse, maka pihak pengelola dan pihak pemodal akan bersama-sama menanggung segala kerugian yang di derita, sesuai dengan porsi modal yang disepakati. Berdasarkan prakteknya hal demikian sulit diterapkan karena pihak bank tidak ingin tau segala macam kerugian yang di derita oleh nasabah pengelola dan baik itu dari faktor kesengajaan atau karena faktor kelalaian sehingga tetap saja agunan yang dimintakan untuk dijadikan salah satu syarat oleh pihak Bank Syariah kepada nasabah/pengelola dana pada akhirnya harus tetap di eksekusi dan hal itu dilakukan guna mengembalikan sejumlah dana/modal yang telah diberikan oleh pihak Bank Syariah yang telah ditentukan sebelumnya. Sehingga prinsip dasar pembiayaan Musyarakah yang berdasarkan pada profit loss-sharing tidak terwujud dan nasabah atau pengelola dana kembali berada pada posisi yang lemah.. 


\section{Identifikasi Masalah}

Berdasarkan masalah yang diuraikan diatas sebagai latar belakang maka penulis mengangkat permasalahan untuk dikaji dalam penulisan ini, yaitu:

1. Apakah penggunaan agunan pada akad Musyarakah di Bank Syariah telah sesuai dengan hukum positif dan ketentuan syariat islam?

2. Bagaimana penyelesaian kredit macet Bank Syariah terkait agunan pada Akad Musyarakah di Bank Syariah?

\section{TINJAUAN PUSTAKA}

\section{Pengertian Bank Syariah}

Bank Syariah menurut peraturan Bank Indonesia nomor 2/8/PBI/2000 ialah Bank umum sebagaimana yang dimaksud dengan Undang-Undang Nomor 7 Tahun1992 Tentang Perbankan dan telah diubah dengan Undang-Undang Nomor 10 Tahun 1998 yang melakukan kegiatan usaha berdasarkan prinsip syariat Islam, termasuk Unit Usaha Syariah dan kantor cabang Bank asing yang melakukan kegiatan usaha berdasarkan prinsip syariat Islam yaitu bagi hasil.

Pengertian Bank Syariah menurut Sudarsono "Bank Syariah adalah lembaga keuangan yang usaha pokoknya memberikan kredit dan jasa-jasa lain dalam lalu lintas pembayaran serta peredaran uang yang beroprasi disesuaikan dengan prinsip-prinsip Syariah". ${ }^{3)}$

Definisi Bank Syariah menurut Undang-Undang Nomor 22 Tahun 2008 Tentang Perbankan Syariah adalah "Bank Syariah adalah Bank yang menjalankan kegiatan usahanya berdasarkan prinsip Syariah dan menurut jenisnya terdiri dari Bank umum Syariah dan Bank Pembiayaan Rakyat Syariah".

Bank Islam adalah institusi keuangan yang menjalankan usaha dengan tujuan menerapkan prinsip ekonomi dan keuangan islam pada area Perbankan. Perbedaan yang mendasar dengan Perbankan konvensional ialah: (i) akad yang dipraktikan dalam Bank Syariah memiliki konsekuensi duniawi dan ukhrawi, (ii) dalam strukturnya terdapat dewan pengawas Syariah yang bertugas mengawasi operasional produk-produk Bank agar sesuai dengan ketentuan Syariah, (iii) bisnis atau usaha yang dibiayai adalah usaha yang halal.

Bank Syariah di Indonesia didasarkan pada prinsip hukum islam. Sistem Bank Syariah menawarkan fungsi dan jasa yang sama dengan sistem Bank konvensional meskipun diikat oleh prinsip-prinsip islam. Prinsip Bank Syariah adalah aturan perjanjian berdasarkan hukum islam antar Bank dan pihak lain untuk penyimpanan dana atau pembiayaan kegiatan usaha maupun kegiatan lainnya sesuai dengan islam.

Selain itu, pada Pasal 1 ayat (27) menyatakan bahwa "prinsip Syariah adalah prinsip hukum islam dalam kegiatan Perbankan berdasarkan Fatwa yang dikeluarkan oleh lembaga yang memiliki kewenangan dalam penetapan Fatwa di bidang Syariah."

Fungsi dan peranan Bank Syariah menurut Sudarsono menyebutkan sebagai berikut:4)

a. Manajer investasi, yang mengelola investasi atas dana nasabah dengan menggunakan akad Mudharabh atau sebagai agen investasi. Dalam hal ini Bank Syariah berfungsi dan berperan untuk menghimpun dana masyarakah dari menginvestasikan dana tersebut secara prinsip-prinsip Syariah.

b. Investor, sebagai investor Bank Syariah melakukan penyaluran dana melalui kegiatan investasi dengan prinsip bagi hasil, jual beli atau sewa. Bank Syariah menginvestasikan dana yang dimiliki maupun dana nasabah yang dipercayakn kepadanya dengan menggunakan alat investasi yang sesuai dengan prinsip Syariah

\footnotetext{
3) Heri Sudarsono, Bank dan Lembaga Keuangan Syari'ah, Ekonisia, Yogyakarta. 2008, hlm 27.
}

4) Ibid 
dan membagi hasil yang diperoleh sesuai nisbah yang disepakati antara Bank dan pemilik modal

C. Penyedia jasa keuangan dan lalu lintas pembayaran, Bank Syariah menyediakan jasa keuangan, jasa non keuangan dan jasa keagenan. Kegiatan ini pada umumnya sama seperti Bank konvensional sepanjang tidak bertentangan dengan prinsip Syariah

d. Pelaksanaan kegiatan sosial, sebagai ciri yang merekat pada entitas keuangan Syariah, Bank islam juga memiliki kewajiban untuk mengeluarkan dan mengelola zakat serta dana-dana sosial lainnya.

Dari fungsi dan peran tersebut dapat disimpulkan bahwa hubungan antara Bank islam dengan nasabahnya baik sebagai dari investor maupun pelaksanaan dari investasi merupakan hubungan secara kemitraan, tidak seperti hubungan pada Bank konvensional yang bersifat debitur-kreditur.

Upaya pencapaiannya keuntungan yang setinggi-tingginya adalah tujuan yang biasa dicanangkan oleh Bank konvensional. Berbeda dengan tujuan Bank konvensional, Bank Syariah berdiri untuk memelihara dan menggembangkan jasa-jasa serta produk-produk Perbankan yang berdasarkan prinsip-prinsip Syariah islam. Bank Syariah juga memiliki kewajiban untuk mendukung aktivitas investasi dan bisnis yang ada di lembaga keuangan, sepanjang aktivitas tersebut tidak dilarang dalam islam. Selain itu, Bank Syariah harus lebih menyentuh kepentingan masyarakat kecil.

\section{Pengertian Akad}

Menurut fuqaha akad memiliki dua pengertian: umum dan khusus. Pengertian umum lebih dekat dengan pengertian secra bahasa dan pengertian ini yang tersebar dikalangan fuqaha malikiyyah, syafr'iyyah dan hanabillah yaitu setiap sesuatu yang ditekadkan oleh seseorang untuk melakukannya baik muncul dengan kehendak sendiri seperti wakaf, ibra' (pengguguran hak) talak, dan sumpah maupun membutuhkan dalam menciptakannya seperti jual beli dan sewa menyewa. Adapun pengertian khusus yang dimaksudkan disini ketika membicarakan tentang teori akad adalah hubungan antara ijab efek terhadap objek. ${ }^{5}$

Akad pada dasarnya dititik beratkan pada kesepakatan antara dua pihak yang ditandai dengan ijab-qabul demikian ijab-qabul adalah suatu perbuatan atau pernyataan untuk menjukan suatu keridhaan dalam berakad yang dilakukan oleh dua orang atau lebih, sehingga terhindar atau keluar dari suatu ikatan yang tidak berdasarkan syara. Karena itu, dalam islam tidak semua bentuk kesepakatan atau perjanjian dapat dikatagorikan sebagai akad, terutama kesepakatan yang tidak didasarkan pada keridhaan dan Syariah Islam. ${ }^{6}$

Rukun Akad

a. Rukun-Rukun Akad

Rukun-rukun akad adalah sebagai berikut :7

1) Aqid

Aqid adalah orang yang berakad (subjek akad).Terkadang masing-masing pihak terdiri dari salah satu orang, terkadang terdiri dari beberapa orang. Misalnya, penjual dan pembeli beras di pasar biasanya masing-masing pihak satu orang berbeda dengan ahli waris sepakat untuk memberikan sesuatu kepada pihak yang lain yang terdiri dari beberapa orang.

2) Ma'qud Alaih

\footnotetext{
${ }^{5}$ Nasrun Haroen, Ensiklopedia Hukum Islam, PT Ichtiar Baru Van Hoeve, 2003, hlm 63

${ }^{6}$ Qamarul Huda, Fiqih Muamalan, Teras, Yogyakarta, 2011, Hlm 25

${ }^{7}$ Ibid
} 
Ma'qud alaih adalah benda-benda yang akan di akadkan (objek akad), seperti benda-benda yang di jual dalam akad jual beli, dalam akad hibah atau pemberian, gadai, dan utang.

3) Maudhu al-Aqid

Maudhu al-Aqid adalah tujuan atau maksud mengadakan akad. berbeda akad maka berbedalah tujuan pokok akad. Dalam akad jual beli misalnya, tujuan pokoknya yaitu memindahkan barang dari penjual kepada pembeli dengan di beri ganti.

4) Shighat al-Aqid

Sighat al-Aqid yaitu ijab qabul. Ijab adalah ungkapan yang pertama kali di lontarkan oleh salah satu dari pihak yang akan melakukan akad, sedangkan qabul adalah pernyataan pihak kedua untuk menerimanya. Pengertian ijab qabul dalam pengalaman dewasa ini ialah bertukarnya sesuatu dengan yang lain sehingga penjual dan pembeli dalam membeli sesuatu. terkadang tidak berhadapan atau ungkapan yang menunjukkan kesepakatan dua pihak yang melakukan akad, misalnya yang berlangganan majalah, pembeli mengirim uang melalui pos wesel dan pembeli menerima majalah tersebut dari kantor pos.

Syarat-syarat dalam akad adalah sebagai berikut $:^{8}$

a. Kedua orang yang melakukan akad cakap bertindak (ahli). Tidak sah akad orang yang tidak cakap bertindak, seperti pengampuan, dan karena boros.

b. Yang di jadikan objek akad dapat menerima hukumnya,

c. Akad itu di izinkan oleh syara, di lakukan oleh orang yang mempunyai hak melakukannya, walaupun dia bukan aqid yang memiliki barang,

d. Janganlah akad itu akad yang di larang oleh syara, seperti jual beli mulasamah. Akad dapat memberikan faedah, sehingga tidaklah sah bila rahn (gadai) di anggap sebagai imbalan amanah (kepercayaan),

e. Ijab itu berjalan terus, tidak di cabut sebelum terjadi qabul. Maka apabila orang berijab menarik kembali ijabnya sebelum qabul maka batallah ijabnya,

f. Ijab dan qabul harus bersambung, sehingga bila seseorang yang berijab telah berpisah sebelum adanya qabul, maka ijab tersebut menjadi batal.

Hukum Islam telah menetapkan beberapa prinsip akad yang berpengaruh kepada pelaksanaan akad yang di laksanakan oleh pihak-pihak yang berkepentingan. Berikut ini prinsip-psrinsip akad dalam Islam:

a. Prinsip kebebasan berkontrak.

b. Prinsip perjanjian itu mengikat.

c. Prinsip kesepakatan bersama.

d. Prinsip ibadah.

e. Prinsip keadilan dan kesemimbangan prestasi.

f. Prinsip kejujuran (amanah).

\section{Pengertian Musyarakah}

Secara bahasa Musyarakah berasal dari kata al-syirkah yang berarti al-ikhtilath (percampuran) atau persekutuan dua hal atau lebih, sehingga antara masing-masing sulit dibedakan. Seperti persekutuan hak milik atau perserikatan usaha. ${ }^{9}$ Secara etimologis,

${ }^{8}$ Ibid

${ }^{9}$ Ghufron A.Mas"adi, Fiqh Muamalah Kontekstual, PT Raja Grafindo Persada, Jakarta, 2002, hlm 191 
Musyarakah adalah penggabungan, percampuran atau serikat. Musyarakah berarti kerjasama kemitraan atau dalam bahasa Inggris disebut partnership. ${ }^{10}$

Secara fiqih, dalam kitabnya, as-Sailul Jarrar III: 246 dan 248, Imam Asy-Syaukani menulis sebagai berikut, "(Syirkah syar'iyah) terwujud (terealisasi) atas dasar sama-sama ridha di antara dua orang atau lebih, yang masing-masing dari mereka mengeluarkan modal dalam ukuran yang tertentu. Kemudian modal bersama itu dikelola untuk mendapatkan keuntungan, dengan syarat masing-masing di antara mereka mendapat keuntungan sesuai dengan besarnya saham yang diserahkan kepada syirkah tersebut. Namun manakala mereka semua sepakat dan ridha, keuntungannya dibagi rata antara mereka, meskipun besarnya modal tidak sama, maka hal itu boleh dan sah, walaupun saham sebagian mereka lebih sedikit sedang yang lain lebih besar jumlahnya. Dalam kacamata syariat, hal seperti ini tidak mengapa, karena usaha bisnis itu yang terpenting didasarkan atas ridha sama ridha, toleransi dan lapang dada. ${ }^{11}$

Musyarakah adalah akad kerjasama yang terjadi di antara para pemilik modal (mitra Musyarakah) untuk menggabungkan modal dan melakukan usaha secara bersama dalam suatu kemitraan, dengan nisbah pembagian hasil sesuai dengan kesepakatan, sedangkan kerugian ditanggung secara proporsional sesuai dengan kontribusi modal. ${ }^{12}$

Musyarakah adalah kemitraan antara bank dan nasabah untuk bersama-sama memberikan modal dengan cara membeli saham untuk membiayai suatu investasi. ${ }^{13}$ Musyarakah merupakan pembiayaan berdasarkan akad kerjasama antara dua pihak atau lebih untuk suatu usaha tertentu, dimana masing-masing pihak memberikan kontribusi dana dengan ketentuan bahwa keuntungan dan risiko akan ditanggung bersama sesuai kesepakatan. Dasar hukum musyarakah berdasarkan Undang-Undang Nomor 21 Tahun 2008 Tentang Perbankan Syariah dan Fatwa DSN No.8.DSN-MUI/IV/2000 Tentang Pembiayaan Musyarakah.

Secara teknis pembiayaan Musyarakah ini diataur dalam Pasal 36 huruf b poin kedua Peraturan Bank Indonesia No. 6/24/PBI/2004 Tentang Bank Umum yang melaksanakan kegiatan usaha berdasarkan prinsip syariah yang pada intinya menyatakan bahwa bank wajib melaksanakan prinsip syariah dan prinsip kehati-hatian dalam melakukan kegiatan usaha yang meliputi penyaluran dana yang menggunakan prinsip bagi hasil berdasarkan akad Musyarakah. ${ }^{14}$

Sebagai landasan Hukum akad pembiayaan Musyarakah antara lain adalah Pasal 19 ayat (1) huruf $\mathrm{c}$ dan ayat (2) huruf $\mathrm{c}$ serta Pasal 21 huruf b angka 1 Undang-Undang Perbankan Syariah, Fatwa Dewan Syariah Nasional Majelis Ulama Indonesia Nomor 08.DSN-MUI/IV/2000 Tentang Pembiayaan Musyarakah, dan Peraturan Bank Indonesia Nomor 7/6/PBI/2005 Tentang Transparansi Informasi Produk Bank dan Penggunaan Data Pribadi Nasabah beserta ketentuan perubahannya PBI Nomor 9/19/PBI/2007 tentang Pelaksanaan Prinsip Syariah dalam Kegiatan Penghimpunan Dana dan Penyaluran Dana serta Pelayanan Jasa Bank Syariah berikut perubahannya dengan Peraturan Bank Indonesia Nomor 10/16/PBI/2008.

\section{Pengertian agunan (jaminan)}

Istilah jaminan merupakan terjemahan dari bahasa Belanda, yaitu zekerheid atau cautie. Zekerheid atau cautie mencakup secara umum cara-cara kreditur menjamin dipenuhinya tagihannya, disamping pertanggungan jawab umum debitur terhadap barang-

\footnotetext{
${ }^{10}$ Mardani, Hukum Bisnis Syariah, Prenadamedia Group, Jakarta, 2014, hlm 142

${ }^{11} \mathrm{Naf}^{\prime \prime}$ an, Pembiayaan Musyarakah dan Mudharabah, Graha Ilmu, Yogyakarta, 2014, hlm.96

12 Ibid

13 Sutan Remy Sjahdeini, Perbankan Islam dan Kedudukannya dalam Tata Hukum Perbankan Indonesia, Pustaka Utama Grafiti, Jakarta, 2007, hlm. 57

${ }^{14}$ Abdul Ghofur Anshori, Perbankan Syariah di Indonesia, Gadjah Mada University Press, Yogyakarta, 2007, hlm 128 .
} 
barangnya. Selain istilah jaminan, dikenal juga dengan agunan. Istilah agunan dapat dibaca dalam Pasal 1 angka 23 Undang-Undang Nomor 10 Tahun 1998 tentang Perubahan atas Undang-Undang Nomor 7 Tahun 1992 Tentang Perbankan.

Agunan adalah : "Jaminan tambahan diserahkan nasabah debitur kepada Bank dalam rangka mendapatkan fasilitas kredit atau pembiayaan berdasarkan prinsip Syariah." Agunan dalam konstruksi ini merupakan jaminan tambahan (accesoir). Tujuan agunan adalah untuk mendapatkan fasilitas dari Bank. Jaminan ini diserahkan oleh debitur kepada Bank. ${ }^{15}$

Di Indonesia telah diatur mengenai hukum jaminan. Pengaturan hukum positif tentang jaminan terdapat dalam Kitab Undang-Undang Hukum Perdata (KUH Perdata) Pasal 11501161. Jaminan merupakan perjanjian yang bersifat accesoir yaitu perjanjian yang bersifat tambahan dan dikaitkan dengan perjanjian pokok. Perjanjian pokok dari jaminan adalah perjanjian pemberian kredit atau pembiayaan. Perjanjian terbagi menjadi dua jenis, yaitu Jaminan Materiil (Kebendaan) dan Jaminan Immateriil (Perorangan). ${ }^{16}$

Unsur-unsur agunan, yaitu : (1). Jaminan tambahan ; (2) Diserahkan oleh debitur kepada Bank ; (3)Untuk mendapatkan fasilitas kredit atau pembiayaan. Didalam Seminar Badan Pembina Hukum Nasional yang diselenggarakan di Yogyakarta, dari tanggal 20 s.d. 30 Juli 1977 disimpulkan pengertian jaminan. Jaminan adalah "menjamin dipenuhinya kewajiban yang dapat dinilai dengan uang yang timbul dari suatu perikatan hukum. Oleh karena itu, hukum jaminan erat sekali dengan hukum benda."

Konstruksi jaminan dalam definisi ini ada kesamaan dengan yang dikemukakan Hartono Hadisoeprapto dan M. Bahsan. Hartono Hadisoeprapto berpendapat bahwa jaminan adalah "Sesuatu yang diberikan kepada kreditur untuk menimbulkan keyakinan bahwa debitur akan memenuhi kewajiban yang dapat dinilai dengan uang yang timbul dari suatu perikatan." Kedua definisi jaminan yang dipaparkan tersebut adalah:

a. Difokuskan pada pemenuhan kewajiban kepada kreditur (Bank);

b. Wujudnya jaminan ini dapat dinilai dengan uang (jaminan materiil);

c. Timbulnya jaminan karena adanya perikatan antara kreditur dengan debitur. ${ }^{17}$

Istilah yang digunakan oleh tokoh lain M. Bahsan adalah jaminan. Ia berpendapat bahwa jaminan adalah "Segala sesuatu yang diterima kreditur dan diserahkan debitur untuk menjamin suatu utang piutang dalam masyarakat." Alasan digunakan istilah jaminan karena: ${ }^{18}$

a. Telah lazim digunakan dalam bidang Ilmu Hukum, dalam hal ini berkaitan dengan penyebutan-penyebutan, seperti hukum jaminan, lembaga jaminan, jaminan kebendaan, jaminan perorangan, hak jaminan, dan sebagainya ;

b. Telah digunakan dalam beberapa peraturan perundang-undangan tentang lembaga jaminan, seperti yang tercantum dalam Undang-Undang Hak Tanggungan dan Jaminan Fidusia.

\footnotetext{
${ }^{15}$ Salim, Perkembangan Hukum Jaminan di Indonesia, PT.Raja Grafindo Persada, Jakarta, 2011, $\operatorname{hlm} .22$

${ }^{16}$ Sri Soedewi Masjchoen Sofwan, Hukum Jaminan di Indonesia Pokok-Pokok Hukum Jaminan dan Jaminan Perseorangan, Liberty Offset Yogyakarta. Yogyakarta. 2001. Cet. II, hlm. 47

${ }^{17}$ Salim, HS, Perkembangan Hukum Jaminan di Indonesia, Rajawali Press, Jakarta, 2014, hlm.44

${ }^{18}$ Ibid, hlm.44-45
} 


\section{PEMBAHASAN}

\section{Penggunaan Agunan pada Akad Musyarakah Bank Syariah Menurut Ketentuan Hukum Positif dan Ketentuan dalam Syariat Islam}

Sejak adanya Bank Syariah di Indonesia yang menjamin ketentuan yang digunakan adalah bagi hasil yang mengenyampingkan urusan dalam riba dan sesuai dengan ajaran Islam yaitu dengan tidak mewajibkan adanya penggunaan agunan pada akad Musyarakah akhirnya Bank Syariah ini menjadi pilihan yang tepat bagi masyarakat Indonesia yang mayoritasnya muslim. Namun dalam prakteknya pihak Bank Syariah sulit untuk menerapkannya, untuk tidak menggunakan agunan pada akad Musyarakah, alasan pihak Bank meminta jaminan adalah karena pada zaman sekarang moral nasabah yang tidak dapat diperkirakan. Kemudian agar nasabah memiliki tanggung jawab terhadap pembiayaan yang diajukannya. Dengan mencantumkan jaminan maka nasabah diharapkan serius dan tidak main-main dalam menjalankan usahanya.

Alasan lainnya karena pihak Bank melihat adanya UU Nomor 21 tahun 2008 pasal 23 ayat (1) dan (2) menyebutkan bahwa (a) Bank Syariah dan/atau Unit Usaha Syariah harus mempunyai keyakinan atas kemauan dan kemampuan calon Nasabah Penerima Fasilitas untuk melunasi seluruh kewajiban pada waktunya, sebelum Bank Syariah dan/atau Unit Usaha Syariah menyalurkan dana kepada nasabah Penerima Fasilitas (b) Untuk memperoleh keyakinan sebagaimana dimaksud pada ayat (1), Bank Syariah dan/atau Unit Usaha Syariah wajib melakukan penilaian yang seksama terhadap watak, kemampuan, modal, agunan, dan prospek usaha dari calon Nasabah Penerima Fasilitas.

Tujuan dari pembebanan agunan terhadap nasabah kreditur sebagaimana penjelasan yang terdapat dalam Pasal 37 ayat (1) dan Pasal 23 Undang-Undang Nomor 21 Tahun 2008 Tentang Perbankan Syariah, menegaskan bahwa "Penyaluran dana berdasarkan Prinsip Syariah oleh Bank Syariah dan Unit Usaha Syariah mengandung risiko kegagalan atau kemacetan dalam pelunasannya sehingga dapat berpengaruh terhadap kesehatan Bank Syariah dan Unit Usaha Syariah". Untuk itu dan/atau Unit Usaha Syariah harus mempunyai keyakinan atas kemauan dan kemampuan calon Nasabah Penerima fasilitas untuk melunasi seluruh kewajiban pada waktunya, sebelum Bank Syariah dan/atau Unit Usaha Syariah menyalurkan dana kepada Nasabah Penerima Fasilitas. memberikan pengertian bahwa jaminan yang dibebankan kepada nasabah debitur adalah untuk melindungi kepentingan Bank Syariah selaku kreditor dari ancaman kerugian. Bank Syariah tidak ingin rugi bila memberikan dana pembiayaannya kepada nasabah debitur, padahal kebersamaan dan kemitraan dalam musyarakah baik untung maupun rugi dijunjung tinggi dan di sisi lain bahwa kedudukan nasabah adalah sejajar.

Kesimpulan menurut hukum positif agunan adalah sesuatu yang diberikan kepada kreditor yang diserahkan oleh debitur untuk menjamin bahwa debitur akan memenuhi kewajiban yang dapat dinilai dengan uang yang timbul dari suatu perikatan.

Fatwa Dewan Syariah Nasional Majelis Ulama Indonesia Nomor 08/DSNMUI/IV/2000 Tentang Pembiayaan Musyarakah juga menyebutkan bahwa dalam pembiayaan musyarakah pada prinsipnya tidak ada jaminan, namun untuk menghindari terjadinya penyimpangan oleh nasabah, Bank Syariah boleh meminta jaminan. Berlandaskan Fatwa tersebut, dalam pembiayaan Musyarakah kedudukan jaminan hanya sebagai bentuk kehatihatian (penerapan prudential banking principle) bukan merupakan syarat mutlak dalam penentuan pemberian pembiayaan Musyarakah oleh pihak Bank Syariah, namun kenyataannya Bank Syariah selalu mewajibkan adanya jaminan kepada nasabah dalam setiap pembiayaan Musyarakah. Keberadaan jaminan sebagai bentuk kehati-hatian menjadi hal yang mutlak harus ada yang harus disediakan oleh pihak nasabah debitur. 
Jaminan yang diserahkan kepada Bank berupa surat-surat bukti kepemilikan saja (secara fidusia), bukan bentuk barangnya yang diserahkan kepada Bank. Barang tersebut masih dapat digunakan oleh nasabah dalam kehidupan sehari-hari. Surat-surat tersebut kemudian diamankan oleh pihak Bank sebagai perlindungan terhadap dananya yang sedang dimusyarakahkan. Jika perjanjian tersebut telah selesai, maka secara otomatis jaminan akan dikembalikan kepada nasabah. Jika ternyata dalam masa perjanjian Musyarakah tersebut nasabah tidak dapat memenuhi kewajibannya, maka pihak Bank akan meneliti apa penyebab terjadinya hal tersebut. Jika diketahui bahwa kendala yang dihadapi dalam menjalankan usaha tersebut adalah bukan akibat kelalaian nasabah, melainkan akibat dari kondisi perekonomian yang terjadi atau force majeur maka pihak Bank akan memberikan kebijakan. Jadi dapat dikatakan bahwa penyertaan agunan dalam pembiayaan Musyarakah merupakan bentuk penerapan prinsip kehati-hatian yang dijalankan oleh pihak Bank guna pengamanan terhadap modal yang diberikan oleh Bank kepada nasabah dan sebagai penguat keseriusan nasabah dalam menjalankan usaha yang akan dijalankan dan sebagai cerminan rasa tanggung jawab atas usaha yang diberikan modal oleh Bank sehingga dapat menjalankan usahanya dengan serius.

Penggunaan agunan pada akad Musyarakah Bank Syariah sudah berjalan sesuai dengan hukum positif namun apabila dihubungkan dengan Fatwa Dewan Syariah Nasional penggunaan agunan pada akad Musyarakah belum sesuai dengan ketentuan yang ada karena masih ada beberapa hal di Bank Syariah yang mengacu pada Bank Konvensional dan tidak sejalan dengan syariat Islam. seharusnya di dalam Bank Syariah, pembiayaan Musyarakah itu berjalan sesuai perspektif fiqih. Namun pada kenyataan dalam hal ini terlihat dari berlakunya agunan sebagai syarat mutlak dalam pembiayaan Musyarakah di Bank Syariah.

Mengacu kepada Pasal 26 ayat (1) Undang-Undang Nomor 21 Tahun 2008 Tentang Perbankan Syariah yang menyebutkan bahwa Kegiatan usaha sebagaimana dimaksud dalam Pasal 19, Pasal 20, dan Pasal 21 dan/atau produk dan jasa syariah, wajib tunduk kepada prinsip syariah. Maka dari itu, Jika di hubungkan dengan Pasal tersebut Undang-Undang Nomor 21 Tahun 2008 Tentang Perbankan Syariah harus mengikuti seluruh ketentuan yang ada dalam Fatwa

\section{Penyelesaian Kredit Macet pada Bank Syariah Terkait Agunan pada Akad Musyarakah}

Bank Syariah mengambil langkah-langkah untuk mengatasi permasalahan dalam penggunaan agunan terkait dalam akad Musyarakah tersebut. Penyelesaiannya yaitu dengan restrukturisasi yang mengacu kepada Surat Edaran Bank Indonesia Nomor 13/9/PBI/2011 antara lain dengan cara re-schedule yaitu dengan mendata seluruh jumlah pembiayaan yang telah dikembalikan oleh nasabah yang kemudian akan didapat sisa pembiayaan yang belum dibayar yang dalam kondisi macet. Jumlah yang telah dibayarkan kepada Bank telah dianggap lunas. Kemudian Bank memberikan tempo kembali terhadap jumlah pembiayaan tersebut. Tujuan dari re-schedule adalah untuk memperkecil jumlah angsuran, sehingga diharapkan bahwa nasabah dapat membayar angsuran dengan jumlah lebih kecil yang pada akhirnya dapat menyelesaikan pelunasan pembiayaannya. Selain re-schedule ada dua tahap lainnya yaitu Persyaratan kembali (Reconditioning) yaitu dengan merubah sebagian atau seluruh persyaratan pembiayaan tanpa menambah sisa pokok kewajiban nasabah yang harus dibayar kan kepada Bank antara lain merubah jadwal pembayaran, merubah jumlah angsuran, merubah jangka waktu, merubah nisbah dalam pembiayaan Mudharabah atau Musyarakah, merubah proyeksi bagi hasil dalam pembiayaan Mudharabah atau Musyarakah, dan pemberian potongan. Selanjutnya tahap Penataan kembali (Restructuring) yaitu dengan cara merubah persyaratan pembiayaan antara lain menambah dana fasilitas pembiayaan Bank Umum Syariah atau Unit Usaha Syariah, konversi akad pembiayaan, konversi pembiayaan 
menjadi surat berharga Syariah berjangka waktu menengah, konversi pembiayaan menjadi penyertaan modal sementara pada perusahaan nasabah yang dapat disertai dengan rescheduling atau reconditioning.

Setelah melakukan restrukturisasi pihak Bank mengasuransikan usaha yang akan dijalankan nasabah, guna melindunginya dari hal-hal yang tak terduga. Itikad baik nasabah akan terbaca pada saat nasabah mengalami suatu kendala dalam pembiayaan. Jika dari jadwal yang disepakati nasabah tidak dapat memenuhi kewajibannya tersebut, dan nasabah tidak cepat melapor kepada pihak Bank, maka pihak Bank akan menunggu selama periode tertentu dan nasabah akan diberikan SPKT (surat pemberitahuan keterangan terlambat). SPKT berisi tentang pemberitahuan kepada nasabah telah mengalami keterlambatan dalam pembayaran kewajibannya sesuai waktu yang tertera dalam SPKT. Kemudian dalam tenggang waktu tiga bulan berikutnya nasabah belum juga memenuhi kewajibannya, maka pihak Bank akan mengeluarkan SP (surat peringatan) pertama. Dalam SP 1 pihak Bank masih bertindak memperingatkan nasabah mengenai jumlah kewajibannya, dan pihak Bank masih memberikan tenggang waktu kepada nasabah. Hal ini tetap berlangsung sampai SP ketiga dengan tenggang waktu per-tiga bulan dalam tiap kali SP. Jika belum ada itikad baik dari nasabah dalam tiga kali SP, maka Bank akan menerbitkan SP keras, yaitu peringatan keras bahwa nasabah belum memenuhi kewajibannya. Berikutnya Bank akan memanggil nasabah jika belum ada tanggapan mengenai pertanggung jawaban kewajibannya tersebut untuk mengeksekusi jaminan guna penyelesaian pembiayaan Musyarakah yang bermasalah.

Sebelum pengeksekusian agunan, pihak Bank memberikan pilhan kepada nasabah apakah agunan tersebut akan dijual sendiri oleh nasabah atau penualan agunan tersebut dilakukan oleh pihak Bank. Agunan yang dieksekusi oleh pihak Bank diserahkan kepada lembaga lelang untuk kemudian dieksekusi. Hasil dari penjualan agunan tersebut diserahkan kepada pihak Bank untuk pengembalian modal yang digunakan dalam pembiayaan Musyarakah. Jika terdapat kelebihan pada harga transaksi barang jaminan milik nasabah, maka pihak Bank akan mengembalikan sisa dari penjualan jaminan tersebut kepada nasabah. Perlu diketahui, bahwa seluruh biaya pelaksanaan eksekusi jaminan adalah tanggung jawab nasabah. Dengan tidak mengurangi dalam ketentuan Pasal 1244 KUHPerdata dan Pasal 1245 KUHPerdata

Pasal 1244 KUHPerdata:

"Debitur harus dihukum untuk mengganti biaya kerugian dan bunga, bila tidak dapat membuktikan bahwa tidak dilaksanakannya perikatan ini atau tidak tepatnya waktu dalam melaksanakan perikatan itu disebabkan oleh suatu hal yang tidak terduga yang tidak dapat dipertanggungjawabkan kepadannya, walaupun tidak ada ikatan buruk padanya."

Selanjutnya Pasal 1245 KUHPerdata:

"Tidak ada penggantian biaya, kerugian dan bunga, bila karena keadan memaksa atau karena hal yang terjadi secara kebetulan, debitur berhalangan untuk memberikan atau berbuat sesuatu sesuatu yang diwajibkan atau melakukan suatu yang diwajibkan atau melakukan sesuatu yang terlarang olehnya."

\section{PENUTUP}

\section{Kesimpulan}

Penggunaan agunan menurut ketentuan hukum positif adalah sesuatu yang diberikan kepada kreditor yang diserahkan oleh debitur untuk menjamin bahwa debitur akan memenuhi kewajiban yang dapat dinilai dengan uang yang timbul dari suatu perikatan. memberikan pengertian bahwa jaminan yang dibebankan kepada nasabah debitur adalah untuk melindungi kepentingan Bank Syariah selaku kreditor dari ancaman kerugian. Bank Syariah tidak ingin rugi bila memberikan dana pembiayaannya kepada nasabah debitur. 
Penyelesaian Kredit Macet pada Bank Syariah Terkait Agunan pada Akad Musyarakah yaitu dengan re-schedule yaitu dengan cara mendata seluruh jumlah pembiayaan yang telah dikembalikan oleh nasabah yang kemudian akan didapat sisa pembiayaan yang belum dibayar yang dalam kondisi macet. Tujuan dari re-schedule adalah untuk memperkecil jumlah angsuran. Apabila sudah ada jadwal yang diberikan kepada nasabah tetapi nasabah tidak dapat memenuhi kewajibannya dan nasabah tidak cepat melapor kepada pihak bank, maka pihak bank akan menunggu selama periode tertentu dan nasabah akan diberikan SPKT (surat pemberitahuan keterangan terlambat). SPKT berisi tentang pemberitahuan kepada nasabah telah mengalami keterlambatan dalam pembayaran kewajibannya sesuai waktu yang tertera dalam SPKT. Jika dalam waktu 3 bulan nasabah belum melakukan kewajibannya maka pihak Bank akan memberikan SP 1 (surat peringatan 1) sampai dengan SP 3, jika tidak ada tanggapan dari nasabah maka agunan harus di eksekusi dengan cara memberikan pilihan kepada nasabah untuk menjualnya sendiri atau dengan pilihan bank yaitu melakukan pelelangan.

\section{Saran}

Sebaiknya penggunaan agunan pada akad musyarakah di bank syariah sesuai dengan hukum positif yang tunduk kepada syariat Islam dan sebaiknya Majelis Ulama Indonesia berkoordinasi dengan pemerintah dalam membuat Undang-undang tentang Perbankan Syariah agar tidak bertolak belakang.

Seharusnya Bank Syariah dalam melakukan penyelesaian kredit macet terkait agunan pada pembiayaan akad Musyarakah tidak perlu mengeksekusi agunan karena ketentuan dari Musyarakah tersebut yaitu berdasarkan kerjasama dan kemitraan

\section{DAFTAR PUSTAKA}

Abdul Ghofur Anshori, Perbankan Syariah di Indonesia, Gadjah Mada University Press, Yogyakarta, 2007

Asmuni Mth., Aplikasi Musyarakah dalam Perbankan Islam., Jurnal Al-mawari edisi XII, Yogyakarta, 2004,

Ghufron A.Mas"adi, Fiqh Muamalah Kontekstual, PT Raja Grafindo Persada, Jakarta, 2002,

Heri Sudarsono, Bank dan Lembaga Keuangan Syari'ah, Ekonisia, Yogyakarta. 2008,

Mardani, Hukum Bisnis Syariah, Prenadamedia Group, Jakarta, 2014,

Nasrun Haroen, Ensiklopedia Hukum Islam, PT Ichtiar Baru Van Hoeve, 2003,

Naf"an, Pembiayaan Musyarakah dan Mudharabah, Graha Ilmu, Yogyakarta, 2014,

Qamarul Huda, Fiqih Muamalan, Teras, Yogyakarta, 2011,

Richard Burton Simatupang, Atas Hukum dalam Bisnis, PT Rineka Cipta, Jakarta, 2003

Salim, Perkembangan Hukum Jaminan di Indonesia, PT.Raja Grafindo Persada, Jakarta, 2011,

Sri Soedewi Masjchoen Sofwan, Hukum Jaminan di Indonesia Pokok-Pokok Hukum Jaminan dan Jaminan Perseorangan, Liberty Offset Yogyakarta. Yogyakarta. 2001. Cet. II,

Salim, HS, Perkembangan Hukum Jaminan di Indonesia, Rajawali Press, Jakarta, 2014,

Sutan Remy Sjahdeini, Perbankan Islam dan Kedudukannya dalam Tata Hukum Perbankan Indonesia, Pustaka Utama Grafiti, Jakarta, 2007, 